\title{
PRESERVATION OF NORMAL HUMAN PLASMA IN THE LIQUID STATE. III. STUDIES ON CHEMICAL AND PHYSICO- CHEMICAL CHANGES DURING THE SECOND YEAR OF STORAGE ${ }^{1,2}$
}

\author{
BY EUGENE L. LOZNER, ₹ F. H. L. TAYLOR, SONIA LEMISH,' REBECCA SNYDER, \\ AND LLOYD R. NEWHOUSER • \\ (From the Naval Medical Research Institute and the Naval Medical School, National Naval Medical \\ Center, Bethesda, Maryland, and the Thorndike Memorial Laboratory, Second and Fourth \\ Medical Services (Harvard) of the Boston City Hospital and the Department of \\ Medicine, Harvard Medical School, Boston, Massachusetts)
}

(Received for publication November 29, 1943)

The present regulations of the National Institute of Health with regard to the preservation of plasma in the liquid state call for an expiration date of one year. In the first paper of this series (1), 235 administrations of plasma preserved in the liquid state at room temperature for between 8 and 16 months were performed with an untoward reaction rate of 0.9 per cent and with the expected proportion of beneficial therapeutic results. The second paper of this series (2) has indicated that except for an inability to determine fibrinogen in plasma preserved in the liquid state for 6 months, there were no significant chemical changes in the total protein, albumin-globulin ratio, or nonprotein nitrogen content of plasma. The clinical innocuousness of plasma preserved for periods longer than 6 months made of interest the investigation of what chemical and physicochemical changes might be taking place during storage of such duration.

\section{METHODS}

Eighteen samples of 11 pools of plasma, prepared by the Blood Plasma Department of the Naval Medical School

1 This article has been released for publication by the Division of Publications, of the Bureau of Medicine and Surgery of the U. S. Navy. The opinions and views set forth in this article are those of the writers and are not to be considered as reflecting the policies of the Navy Department.

2 This work was presented in part at a meeting of The American Human Serum Association, Philadelphia, Pennsylvania, October 22, 1943.

Lieutenant, Medical Corps, United States Naval Reserve.

Ensign, W-V(S)(H), United States Naval Reserve.

- Ensign, W-V(S)(H), United States Naval Reserve.

- Captain, Medical Corps, United States Navy. and preserved in the liquid state at room temperature in Washington, D. C., for between 15 and 24 months, were obtained for chemical and physico-chemical studies. The method of plasma preparation has been described previously (1). Six additional samples of lots, stored for less than a week, served as controls.

Total protein was measured by a modification of the method of Keys (3); albumin-globulin ratio by a modification of Howe's method (4). Fibrinogen determination was attempted unsuccessfully by the recalcification method (5), the salting-out method (6), and the thrombin method (7). Non-protein nitrogen was determined by Keys' method, 3 protein precipitants being employed on aliquots of each sample, 10 per cent trichloroacetic acid, 2.5 per cent trichloroacetic acid, and tungstic acid. The interpretation of the contents of the filtrates was made according to the principles laid down by Hiller and Van Slyke (8). By these principles, the difference between the nitrogen content of the 2.5 per cent trichloroacetic acid filtrate and that of the tungstic acid filtrate is an index of the polypeptide content of the plasma. A wide range of values has been reported for this index in normals $(9,10)$. The limits of this range are stated in Table II. The residual nitrogen was calculated according to Berglund (11) and the range of normal given in Table II is his. Urea was determined by the urease manometric method of Van Slyke (12). Free amino-acids were measured by determining the $\alpha$-amino nitrogen by the ninhydrin-carbon dioxide gasometric method of Hamilton and Van Slyke (13 to 15). Osmometric determinations were made by Davis' (16) modification of the Hepp apparatus (17). Electrophoretic patterns were done by Dr. H. Kahler of the National Cancer Institute, using the Longsworth modification (18) of the Tiselius apparatus (19).

\section{RESULTS}

The chemical findings are presented in the accompanying tables. All findings are presented corrected for the initial dilution by sodium citrate and glucose.

It will be observed from Table I that no gross changes in the chemical determinations of total 
TABLE I

Nitrogen components of pooled human plasma, preserved in the liguid state at room temperature for from 15 to 24 months

\begin{tabular}{l|c|c|c}
\hline \multirow{2}{*}{$\begin{array}{c}\text { Nitrogen } \\
\text { components }\end{array}$} & Normal & \multicolumn{2}{|c}{$\begin{array}{c}\text { Preserved liquid } \\
\text { plasma } \\
\text { (18 samples) }\end{array}$} \\
\cline { 2 - 4 } & Range & Range & Average \\
\hline Total protein & 6.3 to 8.0 & 6.0 to 7.2 & 6.5 \\
\hline Albumin & 3.7 to 5.3 & 3.8 to 5.5 & 4.5 \\
\hline Globulin & 1.9 to 3.6 & 1.6 to 3.4 & 2.3 \\
\hline
\end{tabular}

protein, albumin, or globulin appear to be taking place during the second year of storage. It was impossible to determine fibrinogen by any of the chemical methods for reasons previously explained (2). There is a vague suspicion that the albumin concentrations were running a little higher than expected, and the globulins, a little lower. This is to be borne in mind in connection with the physico-chemical studies discussed below.

Table II presents the findings with respect to the non-protein nitrogen and certain of its components. All of the urea concentrations fell within normal limits. However, the total non-protein nitrogen and the amino-acid nitrogen both increased slightly on prolonged storage.
The former, of course, varied with the protein precipitant used as is discussed below, but in general was 10 to $20 \mathrm{mgm}$. per $100 \mathrm{ml}$. higher than normal. The $\alpha$-amino nitrogens in preserved plasma ran from 5 to $10 \mathrm{mgm}$. per 100 ml. higher than the controls.

The "residual" nitrogen, that is, the nonprotein nitrogen less the $\alpha$-amino and urea nitrogen, also increases slightly on prolonged storage. The significance of this increase was investigated by means of a determination of the "polypeptide index," the difference in nitrogen content between a tungstic acid filtrate and a 2.5 per cent trichloroacetic acid filtrate. The rationale for this "index" is that the tungstic acid precipitates polypeptides whereas this concentration of trichloroacetic does not (8). The polypeptides, by this method, also appear to increase slightly on storage. They ran from 3 to $10 \mathrm{mgm}$. per $100 \mathrm{ml}$. greater than normal. Thus, the increase in non-protein nitrogen would appear to be made up of approximately equal parts of amino-acid and polypeptide nitrogen. Preliminary data utilizing hydrolysis of the proteinfree filtrate are confirmatory of this conclusion.

Of these components of the non-protein nitrogen, thus far, only the $\alpha$-amino nitrogen has been partially correlated with age. It will be observed from Table III that even here the correlation is not perfect.

Non-protein nitrogen components of pooled human plasma, preserved in the liquid state at room temperature for from 15 to 24 months

\begin{tabular}{|c|c|c|c|c|}
\hline \multirow{2}{*}{\multicolumn{2}{|c|}{ Non-protein nitrogen components }} & \multirow{2}{*}{$\begin{array}{c}\text { Normal } \\
\text { Range }\end{array}$} & \multicolumn{2}{|c|}{$\begin{array}{l}\text { Preserved liquid plasma } \\
\text { (18 samples) }\end{array}$} \\
\hline & & & Range & Average \\
\hline \multicolumn{2}{|c|}{ Urea-N } & 10 to $17^{m}$ & $\begin{array}{l}\text { per } 100 \mathrm{ml} . \text { of pl } \\
11.3 \text { to } 16.5\end{array}$ & 14.2 \\
\hline \multicolumn{2}{|c|}{$\alpha$-amino-N (Ninhydrin-Carboxyl) } & 4 to 6 & 8.8 to 13.9 & 10.5 \\
\hline \multirow{4}{*}{ NPN } & Filtrates & & & \\
\hline & 10 per cent $\mathrm{CCl}_{3} \mathrm{COOH}$ & 18 to 30 & 32.3 to 49.7 & 40.1 \\
\hline & 2.5 per cent $\mathrm{CCl}_{3} \mathrm{COOH}$ & 20 to 33 & 35.7 to 51.1 & 44.1 \\
\hline & Tungstic Acid & 18 to 30 & 30.9 to 43.7 & 35.6 \\
\hline \multicolumn{2}{|c|}{$\begin{array}{l}\text { "Polypeptide Index" } \\
\mathrm{NPN} \text { (2.5 per cent } \mathrm{CCl}_{3} \mathrm{COOH} \text { )-NPN (Tungstic Acid) }\end{array}$} & 3 to 8 & 3.2 to 14.8 & 8.4 \\
\hline \multicolumn{2}{|c|}{$\begin{array}{l}\text { "Residual" Nitrogen } \\
\left.\text { NPN(10 per cent CCl }{ }_{3} \mathrm{COOH}\right)-(\text { Urea-N }+ \text { Amino-Acid N) }\end{array}$} & 2 to 12 & 10.5 to 23.2 & 15.3 \\
\hline
\end{tabular}


TABLE III

Correlation of $\alpha$-amino nitrogen with age in pooled human plasma, preserved in the liquid state

\begin{tabular}{|c|c|c|}
\hline \multirow{2}{*}{ Age of plasma } & \multicolumn{2}{|c|}{$\alpha$-amino Nitrogen } \\
\hline & Range & Average \\
\hline & \multicolumn{2}{|c|}{$m g m$. per $100 \mathrm{ml}$. of plasma } \\
\hline $\begin{array}{c}5 \text { days (Control) } \\
\text { (3 samples) }\end{array}$ & 4.9 to 5.7 & 5.2 \\
\hline 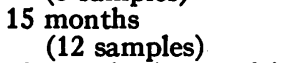 & 8.8 to 11.0 & 9.9 \\
\hline $\begin{array}{l}18 \text { months (1 sample) } \\
19 \text { months (1 sample) } \\
20 \text { months ( } 3 \text { samples) } \\
24 \text { months ( } 1 \text { sample) }\end{array}$ & $\begin{array}{c}10.2 \\
11.8 \\
11.5 \text { to } 14.0 \\
12.1\end{array}$ & $\begin{array}{l}10.2 \\
11.8 \\
12.5 \\
12.1\end{array}$ \\
\hline
\end{tabular}

\section{DISCUSSION}

The 6.3 to 8.0 grams of protein in $100 \mathrm{ml}$. of normal plasma represent from 1000 to $1280 \mathrm{mgm}$. of nitrogen of which from 700 to $1000 \mathrm{mgm}$. is $\alpha$-amino nitrogen (13) upon proper hydrolysis. Thus, the increase of from 5 to $10 \mathrm{mgm}$. of $\alpha$-amino nitrogen, such as was observed here upon storage of plasma in the liquid state for 2 years, represents hydrolysis to this degree of only 0.5 to 1.0 per cent of the original protein.

The highest non-protein nitrogen observed, namely $51.1 \mathrm{mgm}$. per $100 \mathrm{ml}$., indicates hydrolysis to non-protein size of only 2 per cent of the original protein. Thus, from this chemical point of view, 98 to 99.5 per cent of the original precipitable protein can be said to have remained intact. However, gross cleavages of protein may occur without significant increase in $\alpha$-amino or non-protein nitrogen as long as the molecules remain large enough to be precipitable by the usual reagents. Chemical methods, such as the albumin-globulin ratio, have failed to demonstrate conclusively the occurrence of such cleavages in this study. So it has been necessary to turn to physico-chemical methods to clarify this point. Thus far, these data are too incomplete to report in detail. Upon completion, they will be reported in a subsequent paper (20). However, the preliminary electrophoretic analyses and osmometric determinations suggest that such cleavages are, to a certain extent, taking place. The electrophoretic mobilities of the globulin fraction are nearer and invade somewhat the albumin component and the plasma as a whole seems somewhat more effective osmotically than fresh plasma. These changes, however, would not detract from the use of such plasma for its colloid, for example, as an anti-shock agent or in hypoproteinemia, in situations where the labile constituents are unimportant. In fact, if subsequent observations confirm the greater osmotic effectiveness of preserved plasma and fewness of untoward reactions, storage in the liquid state may be most desirable for such indications.

It is of interest to speculate upon the nature of the proteolytic enzyme which may be responsible for the changes observed here. An enzyme resembling trypsin has been prepared from plasma treated with chloroform $(21,22)$. Inasmuch as in preserved plasma, both free amino-acids and polypeptides are increased, the enzyme operating must contain both proteinase and peptidase activity. Therefore, it is not identical with crystalline trypsin of Northrup and Kunitz which does not contain any peptidase activity (15). In its activity at the $\mathrm{pH}$ of plasma, 7.4, it does resemble the enzyme of chloroform-treated plasma which has optimal activity at this $\mathrm{pH}(22)$.

\section{SUMMARY AND CONCLUSIONS}

1. Chemical findings on 18 samples of plasma, preserved in the liquid state for 15 to 24 months at room temperature, are presented.

2. During storage of such duration, the nonprotein nitrogen content, the $\alpha$-amino nitrogen, the "residual" non-protein nitrogen, and the "polypeptide index" all increased slightly.

3. No gross chemical changes can be detected in the total protein, albumin, or globulin content but it appears from the increase in amino-acids and polypeptides that from 0.5 to 2.0 per cent of the original protein is hydrolysed to molecules of these sizes. Therefore, 98 to 99.5 per cent of the original protein remains precipitable.

4. Preliminary electrophoretic and osmometric data indicate that a limited amount of protein cleavage takes place. The osmotic effectiveness of the preserved plasma appears to be slightly increased over fresh plasma.

5. In view of the above findings, it may be concluded that when plasma is prepared by a "closed" system, with scrupulously aseptic technic and careful bacteriologic control, it may be preserved in the liquid state at room 
temperature in a moderate climate for periods up to at least two years.

\section{BIBLIOGRAPHY}

1. Lozner, E. L., and Newhouser, L. R., Preservation of human plasma in the liquid state. I. A statistical study of 1751 administrations. J. Clin. Invest., 1944, 23, 343.

2. Taylor, F. H. L., et al., Preservation of normal human plasma in the liquid state. II. Comparative in vitro studies on the physiologic activity of labile constituents of liquid and frozen plasma. J. Clin. Invest., 1944, 23, 351.

3. Keys, A., A rapid micro-Kjeldahl method. J. Biol. Chem., 1940, 132, 181.

4. Howe, P. E., The determination of proteins in blood. A micro method. J. Biol. Chem., 1921, 49, 109.

5. Cullen, G. E., and Van Slyke, D. D., Determination of the fibrin, globulin, and albumin nitrogen of blood plasma. J. Biol. Chem., 1920, 41, 587.

6. Butler, A. M., and Montgomery, H., The solubility of the plasma proteins. I. Dependence on salt and plasma concentrations in concentrated solutions of potassium phosphate. J. Biol. Chem., 1932, 99, 173.

7. Taylor, F. H. L., Lozner, E. L., and Adams, M. A., The thrombic activity of a globulin fraction derived from rabbit plasma. Am. J. M. Sc., 1941, 202, 585.

8. Hiller, A., and Van Slyke, D. D., A study of certain protein precipitants. J. Biol. Chem., 1922, 53, 253.

9. Hahn, A., Der Doppelstickstoff, ein Diagnostikum für endogenen Eiweisserfall, insbesondere für okkulte eitrige Prozesse. Biochem. Ztschr., 1921, 121, 262.

10. Godfried, E. G., Investigations on the polypeptide content of the serum. Biochem. J., 1939, 33, 955.

11. Berglund, $H$., Nitrogen retention in chronic interstitial nephritis and its significance. J.A.M.A., 1922, 79, 1375.
12. Van Slyke, D. D., Determination of urea by gasometric measurement of the carbon dioxide formed by the action of urease. J. Biol. Chem., 1927, 73, 695.

13. Hamilton, P. B., and Van Slyke, D. D., The gasometric determination of free amino acids in blood filtrates by the ninhydrin-carbon dioxide method. J. Biol. Chem., 1943, 150, 231.

14. Van Slyke, D. D., MacFadyen, D. A., and Hamilton, P., Application of the gasometric ninhydrin- $\mathrm{CO}_{2}$ method to determination of amino acids in blood. Fed. Proc., 1942, 1, 139.

15. Van Slyke, D. D., Dillon, R. T., MacFadyen, D. A., and Hamilton, P., Gasometric determination of carboxyl groups in free amino acids. J. Biol. Chem., 1941, 141, 627.

16. Davis, B., Personal communication.

17. Hepp, O., Ein neues Onkometer zur Bestimmung des Kolloid-osmotischen Druckes. Ztschr. f. d. ges. exp. Med., 1936, 99, 709.

18. Longsworth, L. G., A modification of the schlieren method for use in electrophoretic analyses. J. Am. Chem. Soc., 1939, 61, 529.

19. Tiselius, A., A new apparatus for electrophoretic analysis of colloidal mixtures. Trans. Faraday Soc., 1937, 33, 524.

20. Lozner, E. L., Kahler, H., and Newhouser, L. R., Preservation of normal human plasma in the liquid state. V. Electrophoretic and osmometric studies during the second year of storage. To be published.

21. Tagnon, H. J., Davidson, C. S., and Taylor, F. H. L., Studies on blood coagulation: A proteolytic enzyme prepared from calcium and platelet free normal human blood plasma. J. Clin. Invest., 1942, 21, 525.

22. Kaplan, M. H., Tagnon, H. J., Davidson, C. S., and Taylor, F. H. L., Studies on blood coagulation: The nature and properties of a proteolytic enzyme derived from plasma. J. Clin. Invest., 1942, 21, 533. 